\title{
The paralytic shellfish toxin, saxitoxin, enters the cytoplasm and induces apoptosis of oyster immune cells through a caspase-dependent pathway
}

\author{
Abikhalil Celina ${ }^{1}$, Finkelstein Darren S. ${ }^{2}$, Conejero Genevieve ${ }^{3}$, Du Bois Justin ${ }^{2}$, \\ Destoumieux-Garzon Delphine ${ }^{1}$, Rolland Jean-Luc ${ }^{1,{ }^{*}}$
}

${ }^{1}$ IFREMER, CNRS, Université de Montpellier, Université de Perpignan Via Domitia, IHPE, UMR 5244, F-34095 Montpellier, France

${ }^{2}$ Department of Chemistry, Stanford University, 333 Campus Drive, Stanford, CA 94305-5080, USA

3 Plant Cell Imaging Platform PHIV, UMR B\&PMP (INRA, CNRS, UM, SupAgro), Montpellier, France

*Corresponding address : Jean-Luc Rolland, email address : jean.luc.rolland@ifremer.fr

celina.abi-khalil@umontpellier.fr ; dsfinkel@stanford.edu ; Genevieve.conejero@inra.fr ; jdubois@stanford.edu ; ddestoum@ifremer.fr

\begin{abstract}
:
Exposure of the toxin-producing dinoflagellate Alexandrium catenella (A. catenella) was previously demonstrated to cause apoptosis of hemocytes in the oyster species Crassostrea gigas. In this work, a coumarin-labeled saxitoxin appeared to spread throughout the cytoplasm of the hemocytes. PSTs, including saxitoxin, were also shown to be directly responsible for inducing apoptosis in hemocytes, a process dependent on caspase activation and independent of reactive oxygen species (ROS) production. A series of in vitro labeling and microscopy experiments revealed that STX and analogs there of induced nuclear condensation, phosphatidylserine exposure, membrane permeability, and DNA fragmentation of hemocytes. Unlike in vertebrates, gonyautoxin-5 (GTX5), which is present in high concentrations in A. catenella, was found to be more toxic than saxitoxin (STX) to oyster immune cells. Altogether, results show that PSTs produced by toxic dinoflagellates enter the cytoplasm and induce apoptosis of oyster immune cells through a caspase-dependent pathway. Because of the central role of hemocytes in mollusc immune defense, PST-induced death of hemocytes could negatively affect resistance of bivalve molluscs to microbial infection.
\end{abstract}




\section{Highlights}

- Saxitoxin (STX) appeared to spread throughout the cytoplasm of Crassostrea gigas hemocytes. STX induces a caspase-dependent apoptosis death of hemocytes that does not depend on ROS production. - GTX5, which is present in large amounts in A. catenella, was found to be the most toxic derivate against oyster hemocytes. Hyalinocytes were found to be a hemocyte population highly responsive to this toxic stress.

Keywords : Shellfish, Toxin, Harmful algae, Phytoplankton

\section{Introduction}

Saxitoxin (STX) and its structurally related paralytic shellfish toxin (PST) analogs are potent neurotoxins naturally produced in both freshwater and marine environments by cyanobacteria and dinoflagellates of the genera Alexandrium, Gymnodinium and Pyrodinium (Oshima 1995; Landsberg 2006). These toxins are composed of more than 57 tetrahydropurine derivatives and can be divided into four categories: the $\mathrm{N}$-sulfocarbamoyl, decarbamoyl, deoxydecarbamoyl, and 
carbamate toxins, the latter of which includes saxitoxin (STX) (Wiese et al. 2010). STX and its analogs are water-soluble, acid stable and thermostable molecules (Alfonso et al. 1994) that are produced in large quantities during massive episodic proliferation of dinoflagellates of the Alexandrium genus. PSTs are responsible for major harmful algal blooms (HAB) worldwide (Anderson et al. 2012); consumption of PST-contaminated seafood results in a variety of gastrointestinal and neurologic symptoms known as paralytic shellfish poisoning syndromes that can lead, in extreme cases, to human death (Landsberg et al. 2006).

Although numerous studies have focused on the molecular interactions of STX and its analogs in vertebrate cells, few reports have detailed the cellular effects of PSTs in marine invertebrates and bivalves. Oysters feeding on the neurotoxic dinoflagellates accumulate and transform PSTs in the digestive gland (Bricelj \& Shumway. 1998). Consumption of toxic algae negatively affects the physiological processes of oysters, such as filtration, digestion, and feeding capacity (Bardouil et al. 1996; Huvet et al. 2003; Hegaret et al. 2007a; Rolland et al. 2012), and increases the susceptibility of oysters to parasites (Lassudrie et al. 2015) and pathogenic vibrios (AbiKhalil et al. 2016). Moreover, STX and its analogs have been shown to modulate immunological parameters and gene transcription in mollusc hemocytes (Estrada et al, 2010; Núñez-Acuña et al. 2013; Astuya et al. 2015; Detree et al. 2016). Toxic algae have also been reported to compromise oyster immune cell function by inhibiting cell adhesion and phagocytosis (Hegaret et al. 2011). More recently and in contrast to the non-toxic Alexandrium tamarens, the neurotoxic Alexandrium catenella has been found to induce apoptosis (Medhioub et al. 2013) and mortality (Hegaret et al. 2007b; Lassudrie et al. 2016) in hemocyte immune cells of Crassostrea gigas. 
Hemocytes, which include three populations of blast-like cells, hyalinocytes and granulocytes, are circulating blood cells in oysters (Bachère et al. 1988; Hégaret et al. 2003; Bachère et al. 2015) that play a key role in the maintenance of homeostasis. As cellular mediators of immune response, hemocytes are involved in all steps of the immune response pathway ranging from microbe recognition to pathogen elimination through phagocytosis or encapsulation (Escoubas et al. 2016). Nevertheless, certain bacteria and protozoans pathogenic to oysters have developed mechanism to survive in hemocytes (Duperthuy et al. 2011; Alavi et al. 2009). To counter this, hemocytes induce programmed cell death to control infections. Thus, apoptosis plays an important role in mollusc immunity (Sokolova 2009) and, more generally, in invertebrate immunity (Sokolova 2009; Terahara and Takahashi 2008; Hughes et al. 2010; Zhang et al. 2011). Hemocytes from bivalve molluscs also respond to infection and damage through additional cell death processes such as ETosis, which leads to the extracellular release of antimicrobial DNA traps (Poirier et al. 2014; Robb et al. 2014).

Although filtration of toxic algae by oysters was shown to alter hemocyte functions (Medhioub et al. 2013), it remains unclear whether PSTs directly cause these deleterious effects. Studies were therefore conducted to determine if PSTs, produced by Alexandrium catenella, are responsible for apoptosis of hemocytes in Crassostrea gigas exposed to toxic algae. To assess whether hemocytes are a target for PSTs, oyster hemocytes were exposed to a coumarin-labeled STX, and monitored by multiphoton microscopy to evaluate the cellular localization of STX. Further characterization of apoptotic phenomena in hemocytes exposed to PSTs was accomplished through observation of (i) nuclear condensation, (ii) phosphatidylserine membrane translocation, (iii) membrane permeability and (iv) DNA fragmentation. Analysis of potential 
apoptosis pathways were also explored by measuring caspase activation and ROS production. Finally, the toxicity levels of the main PSTs produced by A. catenella were evaluated. Altogether, these results show that STX enters the cytoplasmic space of oyster immune cells and induces hemocyte apoptosis through a caspase-dependent pathway.

\section{Methods}

\subsection{Oysters and hemocyte collection}

Pacific oyster Crassostrea gigas were produced at the IFREMER Hatchery in Bouin, France (initial average shell length $40 \pm 0.4 \mathrm{~mm}$ ). They were acclimated in the laboratory in a continuous flow of filtered $(10 \mu \mathrm{m})$ seawater at a constant temperature of $20 \pm 1^{\circ} \mathrm{C}$ for two weeks prior to their use for hemolymph extraction.

Hemolymph was extracted from the oyster pericardial cavity through a notch on the shell made two days earlier using a $2 \mathrm{~mL}$ syringe with $0.6 \times 25 \mathrm{~mm}$ needle and kept on ice in a $1.5 \mathrm{~mL}$ tube. The hemolymph from several oysters was pooled on ice before hemocytes were counted under light microscopy using a counting Nageotte chamber.

\subsection{Reagents and solutions}

Paralytic shellfish toxins (PSTs) were obtained from CNRC, Canada. Saxitoxin (STX) was provided as a solution in $3 \mathrm{mM}$ hydrochloric acid while GTX5 and C1/C2 were provided in 17 $\mu \mathrm{M}$ acetic acid. For biological assays, stock solutions of PSTs were adjusted to $50 \mu \mathrm{M}$ in milliQ water. Fluorescent coumarin-coupled saxitoxin (STX-Cou) and coumarin-coupled guanidine (Gua-Cou) were synthesized according to the protocol of Ondrus (Ondrus et al, 2012). 
Stock solutions of DAPI, Mitotraker, Cytox green (Molecular probes), Luminol sodium salt (Sigma), Etoposide (Sigma) and Z-VAD-FMK (Promega), were made according to the recommendations of the manufacturers.

\subsection{STX detection by Multiphoton Microscopy}

Hemocyte monolayers were prepared by depositing hemolymph at a cell density of $5 \times 10^{5}$ cells $/ \mathrm{mL}$ in $20 \mathrm{~mm}$ wells of a cell culture plate (multiwell ${ }^{\mathrm{TM}} 4$ wells, Becton Dickinson Labware) containing a glass slide (13 mm, Thermo scientific). After incubating for $1 \mathrm{~h}$ at room temperature, hemocytes attached to the glass slide were washed three times with $300 \mu \mathrm{L}$ of sterile sea water (SSW). Hemocytes were then incubated with sterile sea water (SSW, control), SSW containing $1 \mu \mathrm{M}$ STX-Cou, or $1 \mu \mathrm{M}$ Gua-Cou used as a negative control. After a $3.5 \mathrm{~h}$ incubation at $20{ }^{\circ} \mathrm{C}$, mitochondria were stained with a PBS solution containing $300 \mathrm{mM}$ of Mitotracker Red (Molecular probes) for $30 \mathrm{~min}$ in a dark room. After three washes with PBS buffer, cells were fixed with $4 \%$ paraformaldehyde and then permeabilized for 10 min with 0.01\% Triton X-100. After three washes with PBS buffer, cells were stained with water containing $1.25 \mu \mathrm{g} / \mathrm{mL}$ of $4^{\prime}, 6^{\prime}$-diamidino-2-phenylindole (DAPI) for $10 \mathrm{~min}$ and fixed with fluorescent mounting medium (DAKO). Cells were subsequently imaged using a Zeiss LSM 780 NLO multi-photon confocal inverted microscope (Regional Cell Imaging platform Montpellier RIO Imaging, www.mri.cnrs.fr). Reference emission spectra of DAPI, STX-Cou, and Mitotracker Red were also recorded (800 nm excitation, emission from 365 to $700 \mathrm{~nm}$, lambda mode on spectral channel) and saved in a spectra database (ZEN software, Zeiss). Linear unmix with the 3 references spectra was then applied to non-exposed hemocytes or hemocytes exposed to STX-Cou or Gua-Cou. 


\subsection{Monitoring of STX-induced apoptosis on hemocytes}

\subsubsection{Nuclear condensation by transmission electron microscopy}

Hemolymph at a cell density of $5 \times 10^{5}$ cells $/ \mathrm{mL}$ in a $1.5 \mathrm{~mL}$ tube was incubated for $3.5 \mathrm{~h}$ in SSW containing $0.8 \mu \mathrm{M}$ STX (CNRC, Canada), SSW (negative control) or SSW containing 50 $\mu \mathrm{M}$ Etoposide (used as an inducer of apoptosis). After centrifugation $\left(5 \mathrm{~min}, 600 \mathrm{~g}, 2{ }^{\circ} \mathrm{C}\right)$, cells were fixed for $1 \mathrm{~h}$ at room temperature in a solution of $2.5 \%$ glutaraldehyde in PHEM buffer (1X, pH 7.4) overnight at $4{ }^{\circ} \mathrm{C}$. Cells were then rinsed in PHEM buffer and post-fixed in a $0.5 \%$ osmic acid solution for $2 \mathrm{~h}$ at room temperature in the dark. After two rinses in PHEM buffer, the cells were dehydrated in a graded series of ethanol solutions (30-100\%). Cells were embedded in EmBed 812 using an Automated Microwave Tissue Processor for Electronic Microscopy, Leica EM AMW. Thin sections (70 nm; Leica-Reichert Ultracut E) were collected at different levels of each block. These sections were counterstained with uranyl acetate $1.5 \%$ in $70 \%$ ethanol and lead citrate and imaged using a Tecnai F20 transmission electron microscope at $200 \mathrm{kV}$ in the CoMET MRI facilities, INM, Montpellier France.

\subsubsection{Phosphatidylserine translocation by Annexin V/ PI assay}

Hemocytes previously attached to glass slides, as described in section 2.3 were incubated with SSW containing $0.8 \mu \mathrm{M}$ or $3.3 \mu \mathrm{M}$ STX (CNRC, Canada), SSW (negative control) or SSW containing $50 \mu \mathrm{M}$ of Etoposide (positive control). After incubating for $3.5 \mathrm{~h}$ at $20{ }^{\circ} \mathrm{C}$, phosphatidylserine translocation and membrane permeability were detected by the "Dead Cell Apoptosis Kit with Annexin V Alexa Fluor ${ }^{\circledR} 488$ \& Propidium Iodide (PI) (Invitrogen, Molecular Probes). Briefly, cells were stained for $15 \mathrm{~min}$ at $20{ }^{\circ} \mathrm{C}$ in the dark with $100 \mu \mathrm{L}$ of 
binding buffer $(1 \mathrm{X})$ containing $5 \mu \mathrm{L}$ of Alexa Fluor® 488 Annexin V and $1 \mu \mathrm{L}$ of PI (100 $\mu \mathrm{g} / \mathrm{mL})$. After three washes with PBS, cells were fixed with $4 \%$ paraformaldehyde and then permeabilized with $0.01 \%$ Triton X-100 for 10 min. After three washes with PBS, cell nuclei were stained for $10 \mathrm{~min}$ with $1.25 \mu \mathrm{g} / \mathrm{mL}$ DAPI (Sigma) then mounted in fluorescent mounting medium (DAKO). Microscopy was performed using a 100x objective on a Zeiss Axio Imager upright fluorescence microscope equipped with an AxioCamMRm 2 digital microscope camera. The image files were then analyzed using FIJI software.

\subsubsection{Membrane permeabilization by Cytox green assay}

Hemocyte membrane permeabilization was monitored as described in Vanhove et al. 2016. Briefly, hemocytes freshly withdrawn from oyster adductor muscle were plated at a cell density of $2 \times 10^{5}$ cells/well on a black 96-well plate with a transparent flat bottom. After a $1 \mathrm{~h}$ incubation at $20^{\circ} \mathrm{C}$, the hemocytes were washed with SSW and incubated for 30 min with $5 \mu \mathrm{M}$ Sytox green (Molecular Probes) diluted in SSW. Then, STX diluted in SSW to a concentration of either 0.8 or $3.3 \mu \mathrm{M}$ was quickly added to the wells and the microplate was immediately placed into a microplate reader infinite M200 (Tecan) to quantify the fluorescence emission every 2 min for 10 hours $\left(\lambda_{\mathrm{ex}}=480 \mathrm{~nm} ; \lambda_{\mathrm{em}}=550 \mathrm{~nm}\right)$. In control wells, STX was substituted by SSW, or SSW containing either $0.1 \%$ Triton or $50 \mu \mathrm{M}$ Etoposide. Results were displayed in relative fluorescence units (RFUs), and were indicative of membrane permeabilization.

\subsubsection{DNA fragmentation by TMRNEL assay}

Hemocytes previously attached to glass slides as described in section 2.3, were incubated with SSW (control) or SSW containing $0.008 \mu \mathrm{M}, 0.08 \mu \mathrm{M}$ or $0.8 \mu \mathrm{M}$ STX (CNRC, Canada) in the 
presence and absence of $100 \mu \mathrm{M}$ of Z-VAD-FMK (Promega), which was used as a pan-caspase inhibitor. Additional assays were performed with SSW containing $0.008 \mu \mathrm{M}, 0.08 \mu \mathrm{M}$ or $0.8 \mu \mathrm{M}$ of the paralytic shellfish toxins C1/C2 or GTX5 (CNRC, Canada) or SSW containing $50 \mu \mathrm{M}$ of Etoposide used as an inducer of apoptosis. Following incubation for either $3.5 \mathrm{~h}$ or $24 \mathrm{~h}$ at $20{ }^{\circ} \mathrm{C}$, cells were fixed with $4 \%$ paraformaldehyde and then permeabilized with $0.01 \%$ Triton X-100 for 10 min. After three washes with PBS, early stages of apoptosis were detected by the tetramethylrhodamine nick end labeling (TMRNEL) assay using the In Situ Cell Death Detection Kit (TMR red, Roche ${ }^{\circledR}$ ). Briefly, incubation with TMRred was performed for 60 min at $37^{\circ} \mathrm{C}$ in the dark according to the manufacturer's recommendations (Roche). After three washes with PBS, cell nuclei were stained for $10 \mathrm{~min}$ with $1.25 \mu \mathrm{g} / \mathrm{mL}$ DAPI (Sigma) then mounted in fluorescent mounting medium (DAKO). For every condition, 30 images were taken randomly over the entire surface of the glass slide (covering a thousand hemocytes) using a 40x objective on a Zeiss Axio Imager upright fluorescence microscope equipped with an AxioCamMRm 2 digital microscope camera. To get higher imaging resolution of the cells, microscopy was performed using a Leica TCS SPE confocal scanning laser microscope (with 40x or 63x objectives). The image files were then analyzed using FIJI software. For each picture, the numbers of DAPI- and TMRNEL-labeled cell nuclei were determined. The percentage of cells showing DNA breaks was determined as a ratio between the number of TMRNEL-labeled cells (red nuclei) and the number of DAPI-labeled cells (blue nuclei).

\subsubsection{Cell viability by colorimetric MTT assay}

Hemocytes freshly withdrawn from oyster adductor muscle were plated at a cell density of $2 \times$ $10^{5}$ cells/well on a 96-well transparent flat bottom plate. After a $1 \mathrm{~h}$ incubation at $20{ }^{\circ} \mathrm{C}$, 
hemocytes were washed with SSW and incubated for $3.5 \mathrm{~h}$ in SSW (control), SSW containing 50 $\mu \mathrm{M}$ of Etoposide, or SSW containing $0.8 \mu \mathrm{M}$ or $3.3 \mu \mathrm{M}$ STX. After a PBS wash, hemocytes were incubated for $3 \mathrm{~h}$ at $20{ }^{\circ} \mathrm{C}$ in $100 \mu \mathrm{L}$ of PBS containing MTT $(5 \mathrm{mg} / \mathrm{mL})$. After another PBS wash, crystals of Formasan (indicative of cell activity) were dissolved in $100 \mu \mathrm{L}$ of DMSO. The blue color derived from dissolved formazan crystal was detected at $550 \mathrm{~nm}$. Results were expressed as a percentage of cell mortality.

\subsubsection{Apoptotic populations by flow cytometry}

Hemocytes at a cell density of $5 \times 10^{5}$ cells/well previously attached to glass slides were incubated for $3.5 \mathrm{~h}$ in SSW (control) or SSW containing $50 \mu \mathrm{M}$ of Etoposide or SSW containing $0.08 \mu \mathrm{M}$ of PSTs (STX, C1/C2 or GTX5). Hemocytes were then treated with trypsin buffer (trypsin $0.2 \%$, EDTA $0.4 \%$ ) for $30 \mathrm{~min}$. Detached cells were fixed with $4 \%$ paraformaldehyde for $1 \mathrm{~h}$ in Eppendorf tubes and centrifuged for $10 \mathrm{~min}$ at $1000 \mathrm{~g}\left(20^{\circ} \mathrm{C}\right)$. Hemocyte pellets were re-suspended in PBS, centrifuged for $5 \mathrm{~min}$ at $600 \mathrm{~g}$ and permeabilized with $0.01 \%$ Triton $\mathrm{X}-100$ for $10 \mathrm{~min}$. After a PBS wash and centrifugation (5 min, 600g, $20{ }^{\circ} \mathrm{C}$ ), hemocytes were labeled with TMRNEL and DAPI as described in section 2.4.4. Hemocytes (10000 per sample) were sorted by size and granularity (blue) as described previously (Bachere et al. 2015) and the percentage of TMRNEL-labeled cells (red) per population was determined using a BD LSR Fortessa $^{\mathrm{TM}}$ flow cytometer analyzer.

Flow cytometry experiments depend on an adhesion step to avoid hemocytes aggregation. Thus, analyses could only be conducted for adherent hemocytes populations such as hyalinocytes and blast-like cells. Unfortunately, the potential effects of PST on granulocytes, a non-adherent hemocyte population, could not be determined. 


\subsection{Reactive Oxygen Species (ROS) production by luminescent assay}

Hemocytes freshly withdrawn from oyster adductor muscle were plated at a cell density of $2 \times$ $10^{5}$ cells/well on a black 96-well plate with a transparent flat bottom. After a $1 \mathrm{~h}$ incubation at 20 ${ }^{\circ} \mathrm{C}$, the hemocytes were washed with SSW and incubated for $1 \mathrm{~h}$ with $1 \mathrm{mM}$ luminol (Sigma, sodium salt) solution diluted in SSW. Then, Zymosan particles (at a multiplicity of infection of 50 particles per hemocyte) or SSW containing STX $(0.8 \mu \mathrm{M})$ were quickly added and the plate was immediately placed into a microplate reader infinite M200 (Tecan) to quantify the luminescence emission every $2 \mathrm{~min}$ for $2 \mathrm{~h}$ (integration time $1500 \mathrm{~ms}$ ). Results were expressed in relative luminescence units (RLUs), which is indicative of luminal oxidation.

\subsection{Statistical Analyses}

All statistical analyses were performed using Graph Pad Prism software. Data were analyzed using a two-way analysis of variance (ANOVA) followed by a post hoc Tukey HSD. Values are the median \pm SD from duplicate per condition and from three independent experiments. Differences were considered significant when $p<0.001$ are represented with a, b, c, d, e superscripts.

\section{Results}

\subsection{Saxitoxin (STX) targets the cytoplasm of oyster hemocytes but not the mitochondria}

The cellular localization of STX within hemocytes was investigated by multiphoton microscopy using a coumarin conjugate of STX (STX-Cou). Fluorescent coumarin labelling was detected in the cytoplasmic space of oyster hemocytes exposed to STX-Cou (Fig. 1). STX-Cou appeared to 
spread throughout the cytoplasm of the hemocytes, but did not co-localize with the Mitotraker dye used to visualize mitochondria (Fig. 1). In addition, minimal fluorescence was observed on hemocytes incubated with the control Gua-Cou, a water-soluble coumarin compound conjugated to a guanidine moiety in place of STX (Fig. S1). These data suggest that the observed fluorescence in hemocytes is STX-specific and that STX accumulates in the cytoplasm of $C$. gigas hemocytes but not in mitochondria.

\subsection{Saxitoxin-treated hemocytes expose phosphatidylserine on the outer leaflet of their plasma}

\section{membrane}

To explore whether STX induced early events of apoptosis, the translocation of membrane phosphatidylserine (PS) from the intracellular side of the plasma membrane to the surface of STX-treated hemocytes was monitored. Hemocytes treated for $3.5 \mathrm{~h}$ with $0.8 \mu \mathrm{M}$ STX were labeled with a green-fluorescent Alexa Fluor ${ }^{\circledR} 488$ Annexin V, which recognizes phosphatidylserine. A strong green fluorescence signal, indicative of phosphatidylserine present at the cell surface, was observed in Etoposide and STX-treated hemocytes, whereas minimal fluorescence was detected in non-exposed hemocytes (controls) (Fig. 2A). Fluorescent signal stemming from propidium iodide (PI) was not observed in hemocytes treated with $0.8 \mu \mathrm{M}$ STX or in non-exposed hemocytes (controls), but was detected in hemocytes treated with high concentrations of STX $(3.3 \mu \mathrm{M})$ and Etoposide $(50 \mu \mathrm{M})$ (Fig. 2A). Taken together, these results show that a low concentration of STX $(0.8 \mu \mathrm{M})$ promotes translocation of phosphatidylserine to the extracellular surface in oyster hemocytes without inducing permeabilization of the cell membrane - a process expected for early stages of apoptosis (Zhang et al. 1996). 


\subsection{Saxitoxin induces membrane permeabilization at high concentration}

To examine dose-dependent membrane permeabilization induced by saxitoxin (STX), we measured Sytox fluorescence on STX-treated hemocytes. In three independent experiments, no membrane permeabilization was observed in hemocytes treated with $0.8 \mu \mathrm{M}$ STX or in control experiments with non-exposed hemocytes (Fig. 2B). Interestingly, $36.9 \pm 14.1 \%$ of the cells present on the hemocyte monolayer were permeabilized when exposed to $3.3 \mu \mathrm{M} \mathrm{STX}$, whereas $10.2 \pm 1.8 \%$ were permeabilized with $50 \mu \mathrm{M}$ Etoposide. These results show that STX induces membrane permeabilization only at high toxin concentrations.

\subsection{Saxitoxin induces cells death in a dose-dependent manner}

To investigate whether saxitoxin (STX) could cause hemocytes death, cell viability MTT assays were performed. No significant differences in cell viability were observed between Crassostrea gigas hemocytes incubated for $3.5 \mathrm{~h}$ with $0.8 \mu \mathrm{M}$ of STX and cells untreated with toxin (Fig. 3). In addition, the extent of nuclear DNA fragmentation in $C$. gigas hemocytes was not influenced by exposure time to $0.8 \mu \mathrm{M}$ of STX (Fig. S2). However, the percentage of living hemocytes decreased after incubation with $3.3 \mu \mathrm{M} \mathrm{STX}(34 \pm 8 \%)$ or $50 \mu \mathrm{M}$ Etoposide $(49 \pm 8 \%)$ relative to the control group $(100 \pm 5 \%)$ (Fig. 3).

\subsection{Saxitoxin-treated hemocytes show higher levels of nuclear condensation}

To characterize hemocyte structural modifications associated with STX exposure, transmission electron microscopy was performed on hemocytes treated for $3.5 \mathrm{~h}$ with $0.8 \mu \mathrm{M}$ STX. Although hemocytes treated with STX displayed normal cytoplasmic organelles and intact plasma membranes, chromatin condensation at the nucleus periphery was noted. Similar observations 
were made in cells treated with Etoposide, a known inducer of apoptosis, while untreated control cells displayed no such effects (Fig. 4). These data show that STX, like Etoposide, induces perinuclear condensation of hemocyte chromatin, a hallmark of apoptosis. Results also support the conclusion that STX does not induce hemocyte necrosis since STX-treated cells displayed no visible signs of cell membrane disruption.

\subsection{Saxitoxin induces DNA fragmentation of oyster hemocytes}

To investigate whether STX induces DNA fragmentation, hemocytes of $C$. gigas were exposed to $0.8 \mu \mathrm{M}$ STX for $3.5 \mathrm{~h}$. In three independent experiments, TMRNEL labeling revealed a significant increase in the number of hemocytes with fragmented nuclear DNA, as indicated by the red fluorescent nuclei in STX-exposed hemocytes (Fig. 5A). After exposing hemocytes for $3.5 \mathrm{~h}$ to STX, $54.8 \pm 2.7 \%$ of hemocytes were deemed TMRNEL-positive based on fluorescence recordings $(\mathrm{p}<0.001)$. In contrast, only $15.5 \pm 3 \%$ of untreated control hemocytes were TMRNEL-positive under identical cell culture conditions. STX thus induces DNA fragmentation in oyster hemocytes, another characteristic of apoptosis.

\subsection{Saxitoxin induces caspase-dependent DNA fragmentation in oyster hemocytes}

To investigate whether DNA fragmentation was dependent on caspase activity, $100 \mu \mathrm{M}$ MZVAD-FMK, a cell-permeable pan-caspase inhibitor, was co-incubated with $0.8 \mu \mathrm{M}$ STX-treated hemocytes. After 3.5 h, TMRNEL-positive cells were counted. As a positive control, Etoposide was also exposed to hemocytes under analogous conditions. In three independent experiments, Z-VAD-FMK significantly inhibited the fragmentation of nuclear DNA induced by STX. In the presence of Z-VAD-FMK ( $\mathrm{p}<0.001$ ), a dramatic decrease in TMRNEL-positive cells from 51.1 
$\pm 1.6 \%$ to $3.6 \pm 0.5 \%$ was measured (Fig. $5 \mathrm{~B}$ ). In non-treated hemocytes (controls), the percentage of TMRNEL-positive cells remained at $8.1 \pm 1.3 \%$ (Fig. 5B). In hemocytes exposed to Etoposide, the percentage of TMRNEL positive cells was $76.8 \pm 1.6 \%$ (Fig. 5B). Taken together, these data suggest that STX induces apoptosis of hemocytes through a caspasedependent pathway.

\subsection{Saxitoxin does not induce Reactive Oxygen Species (ROS) production}

Reactive oxygen species are known to initiate a series of cell death processes characterized in molluscs, including apoptosis (Sokolova. 2009) and ETosis (Robb et al. 2014). The production of ROS in STX-treated hemocytes was therefore measured over the course of $2 \mathrm{~h}$ and compared to ROS production in hemocytes exposed to zymosan, a reagent that induces a strong oxidative burst in oyster hemocytes (Poirier et al. 2014). In contrast to zymosan, STX did not promote formation of detectable levels of ROS in hemocytes over a $2 \mathrm{~h}$ period, suggesting that the STXinduced death of $C$. gigas hemocytes is not triggered by ROS (Fig. 4C).

\subsection{Hyalinocytes are more susceptible to saxitoxin than blast-like cells}

To assess the toxicity of STX in hemocyte populations, DNA fragmentation assays were performed using the TMRNEL method. A significant increase in DNA fragmentation of Crassotrea gigas hemocytes was observed after incubation with $0.8 \mu \mathrm{M}$ of STX $(51.5 \pm 19.7 \%$ of cells were TMRNEL-positive) compared to the control (10.1 $\pm 7.2 \%)$ (Fig. 6A). STX toxicity was also observed in both adherent cells $(54.8 \pm 2.8 \%)$ and non-adherent cells $(37.9 \pm 2.9 \%)$ compared to the toxin-free controls $(15.5 \pm 2.8 \%$ and $18.6 \pm 1.2 \%$, respectively) (Fig. 6A). 
Moreover, using flow cytometry, STX appeared toxic to adherent populations of hyalinocytes and blast-like cells. Both populations exhibited high percentages of cells testing positive for TMRNEL ( $76.6 \pm 0.1 \%$ for hyalinocytes and $32.1 \pm 3.3 \%$ for blast-like cells). In comparison, only $9.4 \pm 0.8 \%$ of hyalinocytes and $0.35 \pm 0 \%$ of blast-like cells were TMRNEL-positive in toxin-free controls (Fig. 6B).

\subsection{GTX5 is more toxic than STX and C1/C2 to oyster hemocytes}

To determine whether STX analogs predominantly produced by A. catenella cause hemocyte toxicity, DNA fragmentation assays were performed using the TMRNEL method. Cells exposed to different concentrations of STX, GTX5 and $\mathrm{C} 1 / \mathrm{C} 2$ for $3.5 \mathrm{~h}$ exhibited an increase in the percentage of TMRNEL-positive cells in a dose-dependent manner (Fig. 7). Crassotrea gigas hemocytes, when treated with a toxin concentration of $0.008 \mu \mathrm{M}$, displayed low levels of DNA fragmentation that were statistically indistiguishable from toxin-free cells (Fig. 7). In contrast, hemocytes exposed to $0.8 \mu \mathrm{M}$ toxin showed significantly higher levels of DNA fragmentation, which were similar for all three toxins, ranging from $48.8 \pm 1.3 \%$ to $51.4 \pm 1.7 \%$. Interestingly, cells incubated with a toxin concentration of $0.08 \mu \mathrm{M}$ resulted in varying levels of DNA fragmentation that was dependent on the toxin identity; GTX was the most toxic $(46.7 \pm 0.6 \%)$ to hemocytes followed by STX $(32.8 \pm 0.2 \%)$ and $\mathrm{C} 1 / \mathrm{C} 2(13.6 \pm 0.6 \%)$. Altogether, these data show that (i) PSTs induce apoptosis in oyster hemocytes in a dose-dependent manner, and that (ii) GTX5 is more toxic than STX and $\mathrm{C} 1 / \mathrm{C} 2$ to $C$. gigas hemocytes.

\section{Discussion}


Our findings suggest that STX enters the cytoplasm of Crassostrea gigas hemocytes and directly induces apoptosis through a caspase-dependent pathway. Previous studies have shown that PSTproducing algae increase the mortality of $C$. gigas hemocytes both in vitro (Hegaret et al. 2011; Lassudrie et al. 2016) and in vivo (Medhioub et al. 2013). However, fundamental features of this process, including key mechanistic details of how specific PSTs cause toxicity, remained poorly characterized. In this study, the application of STX, as well as a series of related congeners, was demonstrated to trigger several biochemical indicators of apoptosis in oyster hemocytes such as caspase-dependent DNA fragmentation, phosphatidylserine translocation at the plasma membrane, and ultimately cell death. Although apoptotic bodies could not be observed by TEM, similar ultrastructural changes were detected upon incubation with either Etoposide or STX. In both cases, hemocytes displayed chromatin condensation at the nuclear periphery, a common sign of apoptosis, without major damage to the membrane. The STX-induced death of oyster hemocytes is also consistent with the fact that STX exposure decreased the number of circulating hemocytes in the giant lions-paw scallop (Estrada et al. 2010). In contrast, other in vitro studies have noted that STX has little effect on the viability of hemocytes in C. gigas (Mello et al. 2013) and Mytilus chilensis (Núñez-Acuña et al. 2013; Astuya et al. 2015; Detree et al. 2016). The dose-dependent effects of STX on hemocyte apoptosis, revealed in this study, may account for these different observations.

Importantly, our findings have demonstrated that STX can accumulate in the cytoplasm of hemocytes and that STX-induced hemocyte death is caspase-dependent. This result is consistent with prior studies in which STX exposure increased the expression of the pro-apoptotic Bax and the executor caspases-3 in Mytilus chilensis (Detree et al. 2016). Observations also corroborate 
the finding that a PST producer stimulates the expression of the executor caspases-3 and -7 in $C$. gigas (Medhioub et al. 2013). Altogether, these data support a mechanism for PST-induced apoptosis in bivalve hemocytes that is independent of ROS production. This observation is consistent with previous studies showing that exposure of $C$. gigas hemocytes to the PSTproducer, Alexandrium minutum, and purified STX decreased ROS production (Hegaret et al. 2011; Mello et al. 2013). Thus, the PST-induced death of hemocytes may result from a ligandreceptor interaction rather than a response to oxidative stress. STX binding to specific targets and/or receptors, however, are unknown in molluscs. In vertebrates, STX blocks neuronal transmission at low nanomolar concentrations by inhibiting voltage-gated $\mathrm{Na}^{+}$channels in nerve and muscle cells (Kao 1972; Narahashi 1972; Cestele and Catterall 2000). STX also binds to several other proteins including potassium and calcium channels (Wang et al. 2003), copper transporters (Cusick et al. 2012), and saxiphilin, an iron-binding protein (Morabito et al. 1995; Llewellyn and Moczydlowski 1994). Further characterization of potential cellular targets of STX in molluscs is thus imperative for understanding its cytotoxic effects.

Toxicity studies among select PSTs were conducted, and GTX5 was found to be the most toxic PST to oyster hemocytes. This observation differs from prior reports of the relative toxicity of PSTs in a mouse bioassay, in which STX was found to be most toxic and GTX5 ten times less so (Oshima 1995; EFSA, 2009a). Based on these conflicting data, different cell receptors may be involved in PST-recognition in mammals and molluscs. That GTX5 clearly induces apoptosis is consistent with (i) the apoptotic effects reported for GTX5-producers Alexandrium catenella (Medhioub et al. 2013) and Gymnodinium catenatum (Estrada et al. 2014), and (ii) the lack of apoptotic effects of Alexandrium minutum, whose toxin profile is composed exclusively of 
GTX2 and GTX3 (Touzet et al. 2006). Interestingly, oysters feeding on A. catenella have a toxin profile rich in GTX2 and C2 but devoid of GTX5 suggesting that bioconversion of paralytic toxins occurred (Abi-Khalil et al. 2016). We hypothesize that bioconversion of GTX5 in oyster tissues confers protection against hemocyte death.

Physical or chemical stressors can trigger programmed cell death in mollusc hemocytes. Among others, cadmium chloride induces in vitro apoptosis of hemocytes in $C$. virginica through a mitochondria/caspase-independent pathway (Sokolova et al. 2004). Similarly, UV light causes apoptosis in hemocytes of Ostrea edulis (Gervais et al. 2015). PST-induced programmed cell death may have important consequences on oyster defense from pathogens, as hemocytes play a key role in oyster immune response. These cell types are involved in a series of cellular immune reactions, such as phagocytosis of invading microorganisms, formation of nodules and capsules surrounding pathogens and their subsequent degradation through the release of host defense molecules (Bachere et al. 2015). Hemocytes are able to migrate from the hemolymph to connective tissues and promote localized responses following injury or microorganism invasion. Thus, enhanced apoptosis in hemocytes, induced by STX, has the potential to generate an immune-suppressed organism with reduced capacity to resist pathological insults and opportunistic infections. From the present study, we hypothesize that PST-induced apoptosis of hemocytes in oysters exposed to Alexandrium catenella could result in a reduced capacity of such oysters to resist Vibrio infection (Abi-Khalil et al. 2016).

\section{Conclusion}


In the present paper, PSTs were demonstrated to induce apoptosis in oyster hemocytes. In Crassostrea gigas hemocytes, toxicity was found to be caspase-dependent, but did not result from ROS production. GTX5, which is present in large amounts in A. catenella, was identified as the most toxic of the three PSTs tested against oyster hemocytes. Because hemocyte function is essential for proper immune response, PST-induced death of these cell types could severely compromise mechanisms of defense in bivalve molluscs and decrease resistance to microbial infection.

Acknowledgments: We are grateful to Dr. Guillaume Charrière, Evelyne Bachère and Prof. Stephen Baghdiglian for critical advice with cell biology. We are also grateful to Chantal Cazevieille for her help with TEM. This work received financial support from the Ecosphère Continentale et Côtière (EC2CO) Microbien project (Apotox 2012-2014) and from the National Institutes of Health (JD, grant \# R01-NS045684). Celina Abi-khalil PhD was the recipient of a PhD grant from the University of Montpellier (EcoleDoctorale GAIA: Biodiversité, Agriculture, Alimentation, Environnement, Terre, Eau).

Author Contributions: C.A.K., D.D.G and J.L.R. conceived and designed the experiments. C.A.K. and J.L.R. performed the experiments. C.A.K., D.D.G and J.L.R. analyzed the data. G.C., J.D. and D.S.F. contributed reagents/materials/analysis tools. C.A.K., D.D.G. and J.L.R. wrote the paper.

Conflict of Interest: The authors declare no conflict of interest. 


\section{References}

Abi-Khalil C, Lopez-Joven C, Abadie E, Savar V, Amzil Z, Laabir M, et al. 2016. Exposure to the Paralytic Shellfish Toxin Producer Alexandrium catenella Increases the Susceptibility of the Oyster Crassostrea gigas to Pathogenic Vibrios. Toxins 8(1).

Alavi MR, Fernandez-Robledo JA, Vasta GR. 2009. Development of an in vitro assay to examine intracellular survival of Perkinsus marinus trophozoites upon phagocytosis by oyster (Crassostrea virginica and Crassostrea ariakensis) hemocytes. The Journal of parasitology 95(4): 900-907.

Alfonso A, Louzao MC, Vieytes MR, Botana LM. 1994. Comparative-study of the stability of saxitoxin and neosaxitoxin in acidic solutions and lyophilized samples. Toxicon 32(12): 15931598.

Anderson D.M, Alpermann, T.J, Cembella A.D, Collos Y, Masseret E, Montresor M. 2012. The globally distributed genus Alexandrium: Multifaceted roles in marine ecosystems and impacts on human health. Harmfull Algae 14:10-35.

Astuya A, Carrera C, Ulloa V, Aballay A, Nunez-Acuna G, Hegaret H, Gallardo-Escarate C. 2015. Saxitoxin Modulates Immunological Parameters and Gene Transcription in Mytilus chilensis Hemocytes International Journal of molecular Sciences 16(7): 15235-15250. 
Bachere E, Gueguen Y, Gonzalez M, de Lorgeril J, Garnier J, Romestand B. 2004. Insights into the anti-microbial defense of marine invertebrates: the penaeid shrimps and the oyster Crassostrea gigas. Immunological Reviews 198: 149-168.

Bachere E, Rosa RD, Schmitt P, Poirier AC, Merou N, Charriere GM, et al. 2015. The new insights into the oyster antimicrobial defense: Cellular, molecular and genetic view. Fish Shellfish Immunol 46(1): 50-64.

Bardouil M, Bohec M, Bougrier S, Lassus P, Truquet P. 1996. Feeding responses of Crassostrea gigas (Thunberg) to inclusion of different proportions of toxic dinoflagellates in their diet. Oceanol. Acta. 19: 177-182.

Bricelj V.M, Shumway S.E. 1998. Paralytic shellfish toxins in bivalve molluscs: occurrence, transfer kinetics and biotransformation. Fisheries Science 6 (4): 315-383.

Cestele S, Catterall WA. 2000. Molecular mechanisms of neurotoxin action on voltage-gated sodium channels. Biochimie 82(9-10): 883-892.

Cusick KD, Minkin SC, Dodani SC, Chang CJ, Wilhelm SW, Sayler GS. 2012. Inhibition of copper uptake in yeast reveals the copper transporter Ctr1p as a potential molecular target of saxitoxin. Environmental science \& technology 46(5): 2959-2966. 
Detree C, Nunez-Acuana G, Roberts S, Gallardo-Escarate C. 2016. Uncovering the Complex Transcriptome Response of Mytilus chilensis against Saxitoxin: Implications of Harmful Algal Blooms on Mussel Populations Plos One 11(10).

Duperthuy M, Schmitt P, Garzon E, Caro A, Rosa RD, Le Roux F, et al. 2011. Use of OmpU porins for attachment and invasion of Crassostrea gigas immune cells by the oyster pathogen Vibrio splendidus. Proceedings of the National Academy of Sciences of the United States of America 108(7): 2993-2998.

Escoubas JM, Gourbal B, Duval D, Green TJ, Charrière GM, Destoumieux-Garzón D, et al. 2016. Immunity in Molluscs. In: Encyclopedia of Immunobiology, Vol. 1, (Ratcliffe MJH, ed). Oxford: Academic Press, 417-436

Estrada N, Ascencio F, Shoshani L, Contreras RG. 2014. Apoptosis of hemocytes from lionspaw scallop Nodipecten subnodosus induced with paralyzing shellfish poison from Gymnodinium catenatum. Immunobiology 219(12): 964-974.

Galluzzi L, Vitale I, Abrams JM, Alnemri ES, Baehrecke EH, Blagosklonny MV, et al. 2012. Molecular definitions of cell death subroutines: recommendations of the Nomenclature Committee on Cell Death 2012. Cell Death Differ 19(1): 107-120.

Gervais O, Renault T, Arzul I. 2015. Induction of apoptosis by UV in the flat oyster, Ostrea edulis. Fish Shellfish Immunol 46(2): 232-242. 
Hegaret H, da Silva PM, Wikfors GH, Haberkorn H, Shumway SE, Soudant P. 2011. In vitro interactions between several species of harmful algae and haemocytes of bivalve molluscs. Cell Biol Toxicol 27(4): 249-266.

Hegaret H, Wikfors GH, Shumway SE. 2007a. Diverse feeding responses of five species of bivalve mollusc when exposed to three species of harmful algae. Journal of Shellfish Research 26(2): 549-559.

Hegaret H, Wikfors GH, Soudant P. 2003. Flow cytometric analysis of haemocytes from eastern oyster, Crassostrea virginica, subjected to a sudden temperature elevation I. Heamocyte type and morphology. J Exp Mar Biol Ecol 293:237-248.

Hegaret H, Wikfors GH, Soudant P, Lambert C, Shumway SE, Berard JP, Lassus P. 2007 b. Toxic dinoflagellates (Alexandrium fundyense and A-catenella) have minimal apparent effects on oyster hemocytes. Marine Biology 152(2): 441-447.

Hughes FM, Foster B, Grewal S, Sokolova IM. 2010. Apoptosis as a host defense mechanism in Crassostrea virginica and its modulation by Perkinsus marinus. Fish Shellfish Immunol 29(2): 247-257. 
Huvet A, Daniel J.Y, Quere C, Dubois S, Prudence M, van Wormhoudt A et al. 2003. Tissue expression of two alpha-amylase genes in the Pacific oyster Crassostrea gigas. Effects of two different food rations. Aquaculture 228, 321-333.

Kao CY. 1972. Pharmacology of tetrodotoxin and saxitoxin. Federation proceedings 31(3): 1117-1123.

Kroemer G, Galluzzi L, Vandenabeele P, Abrams J, Alnemri ES, Baehrecke EH, et al. 2009. Classification of cell death: recommendations of the Nomenclature Committee on Cell Death 2009. Cell Death Differ 16(1): 3-11.

Landsberg JH, Hall S, Johannessen JN, White KD, Conrad SM, Abbott JP, et al. 2006. Saxitoxin puffer fish poisoning in the United States, with the first report of Pyrodinium bahamense as the putative toxin source. Environmental health perspectives 114(10): 1502-1507.

Lassudrie M, Soudant P, Nicolas JL, Miner P, Le Grand J, Lambert C, et al. 2016. Exposure to the toxic dinoflagellate Alexandrium catenella modulates juvenile oyster Crassostrea gigas hemocyte variables subjected to different biotic conditions. Fish Shellfish Immunol 51: 104-115.

Lassudrie M, Wikfors GH, Sunila I, Alix JH, Dixon MS, Combot D, Soudant P, Fabioux C, Hegaret H. 2015. Physiological and pathological changes in the eastern oyster Crassostrea virginica infested with the trematode Bucephalus sp and exposed to the toxic dinoflagellate Alexandrium fundyense. Journal of Invertebrate Pathology 126:51-63. 
Llewellyn LE, Moczydlowski EG. 1994. Characterization of saxitoxin binding to saxiphilin, a relative of the transferrin family that displays $\mathrm{pH}$-dependent ligand binding. Biochemistry 33(40): 12312-12322.

Mello DF, da Silva PM, Barracco MA, Soudant P, Hegaret H. 2013. Effects of the dinoflagellate Alexandrium minutum and its toxin (saxitoxin) on the functional activity and gene expression of Crassostrea gigas hemocytes. Harmful Algae 26: 45-51.

Medhioub W, Ramondenc S, Vanhove AS, Vergnes A, Masseret E, Savar V, et al. 2013. Exposure to the Neurotoxic Dinoflagellate, Alexandrium catenella, Induces Apoptosis of the Hemocytes of the Oyster, Crassostrea gigas. Marine drugs 11(12): 4799-4814.

Morabito MA, Llewellyn LE, Moczydlowski EG. 1995. Correction: Molecular Cloning of Bullfrog Saxiphilin: A Unique Relative of the Transferrin Family that Binds Saxitoxin.

Proceedings of the National Academy of Sciences 92(14): 6651-6651.

Narahashi T. 1972. Mechanism of action of tetrodotoxin and saxitoxin on excitable membranes. Federation proceedings 31(3): 1124-1132.

Nunez-Acuna G, Aballay AE, Hegaret H, Astuya AP, Gallardo-Escarate C. 2013. Transcriptional responses of Mytilus chilensis exposed in vivo to saxitoxin. Journal of Molluscan studies 79: 3.23-331 
Ondrus AE, Lee HLD, Iwanaga S, Parsons WH, Andresen BM, Moerner WE, Du Bois J. 2012. Fluorescent Saxitoxins for Live Cell Imaging of Single Voltage-Gated Sodium Ion Channels beyond the Optical Diffraction Limit. Chemistry \& Biology 19 (7): 902-912.

Oshima Y. 1995 Chemical and enzymatic transformation of paralytic shellfish toxins in marine organisms. : Lavoisier Publishine ILP (ed) .Lassus, P., Arzul, G., Erard-Le Denn, E., Gentien, P., Marcaillou-Le baut, C.

Poirier AC, Schmitt P, Rosa RD, Vanhove AS, Kieffer-Jaquinod S, Rubio TP, et al. 2014. Antimicrobial histones and DNA traps in invertebrate immunity: evidences in Crassostrea gigas. The Journal of biological chemistry 289(36): 24821-24831.

Robb CT, Dyrynda EA, Gray RD, Rossi AG, Smith VJ. 2014. Invertebrate extracellular phagocyte traps show that chromatin is an ancient defence weapon. Nature communications 5: 4627.

Rolland JL, Pelletier K, Masseret E, Rieuvilleneuve F, Savar V, Santini A, et al. 2012. Paralytic Toxins Accumulation and Tissue Expression of alpha-Amylase and Lipase Genes in the Pacific Oyster Crassostrea gigas Fed with the Neurotoxic Dinoflagellate Alexandrium catenella. Marine drugs 10(11): 2519-2534. 
Sokolova IM. 2009. Apoptosis in molluscan immune defense. Isj-Invertebrate Survival Journal 6(1): 49-58.

Sokolova IM, Evans S, Hughes FM. 2004. Cadmium-induced apoptosis in oyster hemocytes involves disturbance of cellular energy balance but no mitochondrial permeability transition. The Journal of experimental biology 207(Pt 19): 3369-3380.

Terahara K, Takahashi KG. 2008. Mechanisms and immunological roles of apoptosis in molluscs. Current pharmaceutical design 14(2): 131-137.

Terahara K, Takahashi KG, Nakamura A, Osada M, Yoda M, Hiroi T, et al. 2006. Differences in integrin-dependent phagocytosis among three hemocyte subpopulations of the Pacific oyster "Crassostrea gigas". Developmental and comparative immunology 30(8): 667-683.

Touzet N, Franco JM, Raine, R. 2006. Inter- and intra-specific variability in morphogenetics and toxin composition of Alexandrium spp. in Irish coastal waters. African Journal of Marine Science 28(2): 181-184.

Vanhove AS, Rubio TP, Nguyen AnN, Lemir A, Roche D et al. 2016. Copper homeostasis at the host vibrio interface: lessons from intracellular vibrio transcriptomics. Environmental Microbiology 18(3): 875-888. 
Wang J, Salata JJ, Bennett PB. 2003. Saxitoxin is a gating modifier of HERG K+ channels. The Journal of general physiology 121(6): 583-598.

Wiese M, D'Agostino PM, Mihali TK, Moffitt MC, Neilan BA. 2010. Neurotoxic alkaloids: saxitoxin and its analogs. Marine drugs 8(7): 2185-2211.

Zhang G, Gurtu V, Martin S, Kain SR. 1996. Redistribution of plasma membrane phosphatidylserine occurs during an early stage of apoptosis. Molecular Biology of the Cell 7: 1109-1109.

Zhang L, Li L, Zhang G. 2011. Gene discovery, comparative analysis and expression profile reveal the complexity of the Crassostrea gigas apoptosis system. Developmental and comparative immunology 35(5): 603-610. 


\section{Figures}

Figure 1. Localization of saxitoxin-coumarin (STX-Cou) in hemocytes of Crassotrea gigas.

(A) Reference spectra emissions of DAPI (blue), Mitotracker Red (red) and Coumarin (green), (B) Spectrum of non-exposed hemocytes, (C) spectrum of hemocytes exposed for $3.5 \mathrm{~h}$ to STXCou (nuclei are stained in blue, mitochondria in red, and STX-Cou in green). Scale bar: $10 \mu \mathrm{m}$.

Figure 2. Phosphatidylserine translocation and membrane permeabilization analysis of Crassotrea gigas hemocytes exposed to saxitoxin (STX). (A) Fluorescent microscope pictures of hemocytes after Annexin V Alexa Fluor® 488 and Propidium Iodide (PI) and DAPI staining (nuclei are stained in blue, permeabilized cells nuclei in red and phosphatidylserine in green). Pictures were acquired on a Zeiss Axio Imager upright fluorescence microscope (x100) Scale bar: $50 \mu \mathrm{m}$. (B) Percentage of hemocytes with permeabilized membranes determined through Cytox green incorporation. Non-exposed hemocytes (white column), hemocytes exposed to 50 $\mu \mathrm{M}$ Etoposide (black column), 0.1\% triton (grey column with a black outline), $0.8 \mu \mathrm{M}$ STX (grey column), or $3.3 \mu \mathrm{M}$ STX (dashed grey column). Bars represent the mean \pm standard errors from three independent experiments. Different superscripts $(a, b)$ indicate statistically significant differences ( $p<0.001$; two way anova/ Tukey HSD).

Figure 3. Viability of Crassostrea gigas hemocytes evaluated through the 3-(4,5dimethylthiazol-2-yl)-2,5-diphenyltetrazolium bromide (MTT) assay after exposure to STX for 3.5 h. Percentage of viable non-exposed hemocytes (white column) and hemocytes exposed to either $50 \mu \mathrm{M}$ Etoposide (black column), $0.8 \mu \mathrm{M}$ STX (grey column), or $3.3 \mu \mathrm{M}$ STX (dashed 
grey column). Bars represent the mean \pm standard errors from three independent experiments. Different superscripts (a and b) indicate statistically significant differences $(p<0.001$; two way anova/ Tukey HSD).

\section{Figure 4. Electronic microscopic picture of nuclear condensation of Crassotrea gigas}

hemocyte after exposure to STX. Hemocytes exposed for $3.5 \mathrm{~h}$ to $50 \mu \mathrm{M}$ of Etoposide (right), $0.8 \mu \mathrm{M}$ STX (middle), or non-exposed (left). Nucleus $(\mathrm{N})$, peripheral nuclear condensation is indicated by arrows. Scale bar: $2 \mu \mathrm{m}$.

Figure 5. Fragmentation of nuclear DNA and lack of ROS production of Crassotrea gigas hemocyte exposed to STX. (A) Fluorescent imaging of hemocytes exposed for $3.5 \mathrm{~h}$ to $0.8 \mu \mathrm{M}$ STX. The images were acquired on a confocal microscope (x63) after tetramethylrhodamine nick end labelling (TMRNEL) and DAPI staining (total nuclei are stained in blue and nuclei with DNA breaks in red). Scale bar: $50 \mu \mathrm{m}$. (B) Percentage of TMRNEL positive hemocytes nonexposed (white column), exposed for $3.5 \mathrm{~h}$ to $50 \mu \mathrm{M}$ of Etoposide (black column), or exposed to $0.8 \mu \mathrm{M}$ of either STX alone (grey column) or STX supplemented with $100 \mu \mathrm{M}$ of Z-VAD-FMK (dashed grey column). Bars represent the mean \pm standard errors from three independent experiments. Different superscripts indicate statistically significant differences $(p<0.001$; two way anova/ Tukey HSD). (C) ROS production of hemocytes non-exposed (control, blue line), exposed for $3.5 \mathrm{~h}$ to $0.8 \mu \mathrm{M}$ STX (green line), or exposed to Zymosan at a multiplicity of infection of 50: 1 (positive control, red line). RLUs: Relative Luminescence Units of luminol oxidation. 
Figure 6. Toxicity analysis of Crassostrea gigas hemocytes populations exposed to STX. (A) Fluorescent imaging analysis of hemocytes exposed for $3.5 \mathrm{~h}$ to $0.8 \mu \mathrm{M}$ STX. The images were acquired on a confocal microscope (63X) after tetramethylrhodamine nick end labelling (TMRNEL) and DAPI staining (total nuclei are stained in blue and nuclei with DNA breaks in red). (B) Flow cytometry analysis of two populations of adherent hemocytes, hyalinocyte and blast-like cells, exposed for $3.5 \mathrm{~h}$ to $0.8 \mu \mathrm{M}$ STX. 10,000 cells of each condition and TMRNELpositive hemocytes cell populations were sorted by size. Percentage of non-exposed TMRNEL positive hemocytes (white column), or exposed for $3.5 \mathrm{~h}$ to $0.8 \mu \mathrm{M}$ STX alone (dark grey column). Bars represent the mean \pm standard errors from three independent experiments. Different superscripts indicate statistically significant differences $(p<0.001$; two way anova/ Tukey HSD).

Figure 7. Toxicity analysis of Crassostrea gigas hemocytes exposed to STX analogs. Analysis of TMRNEL-positive cells of hemocytes exposed for $3.5 \mathrm{~h}$ to $0.008 \mu \mathrm{M}, 0.08 \mu \mathrm{M}$, or $0.8 \mu \mathrm{M}$ STX (black column), GTX5 (dark grey column), or C1/C2 (light grey column). Bars represent the mean \pm standard errors from three independent experiments. Different superscripts (a, b, c, d and e) indicate statistically-significant differences ( $p<0.001$; two way anova/ Tukey HSD). 


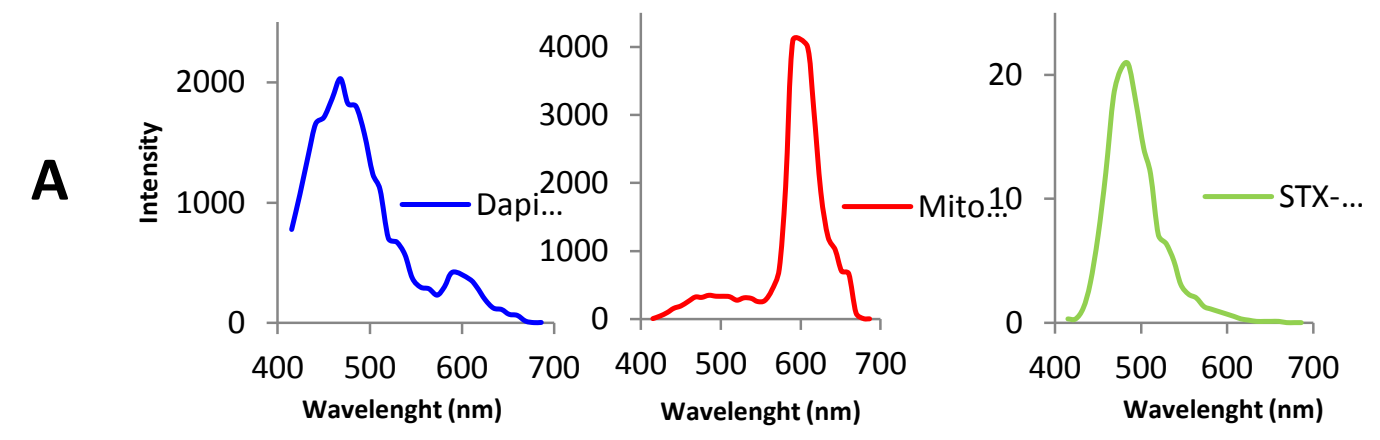

B
DAPI
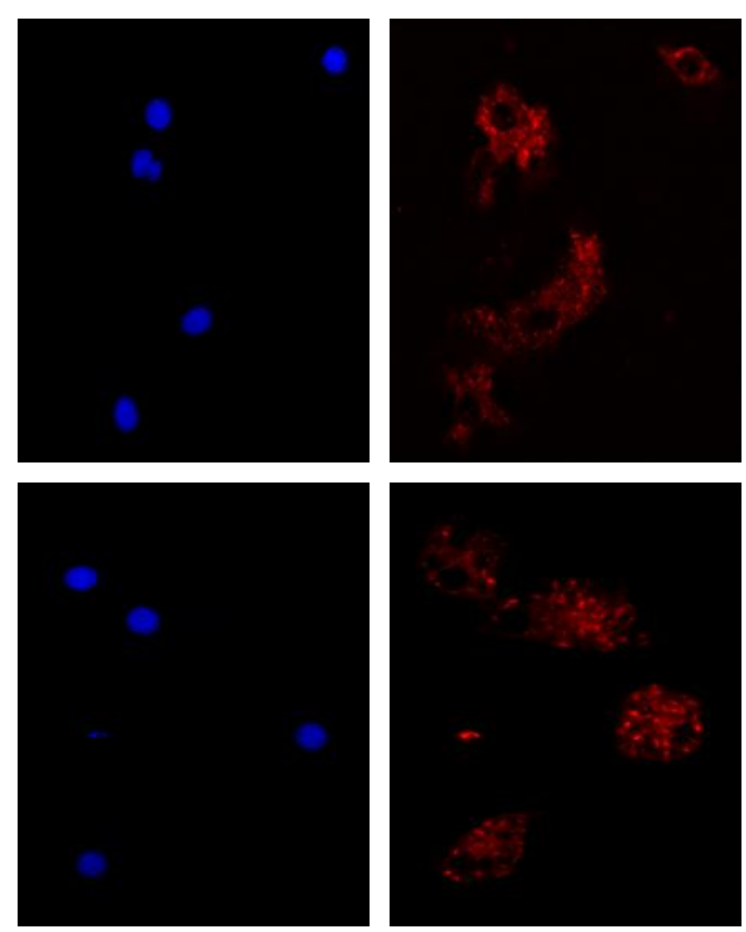

Mitotracker

Coumarin
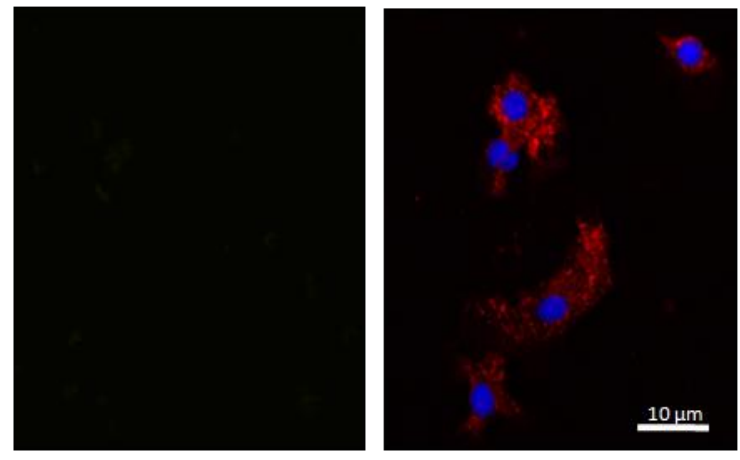

C

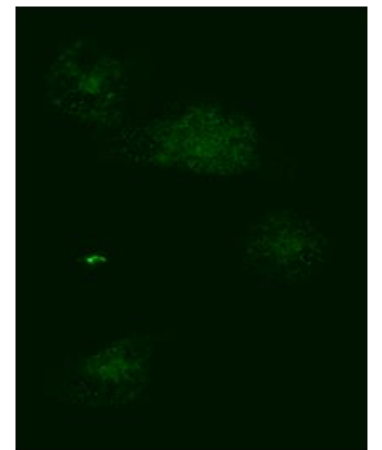

Merge

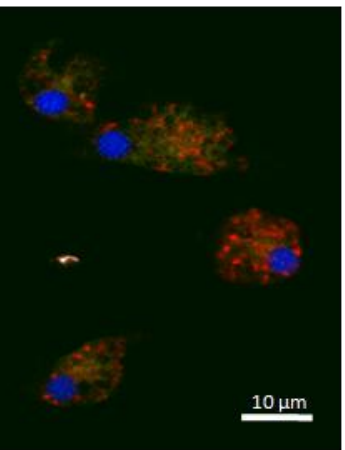




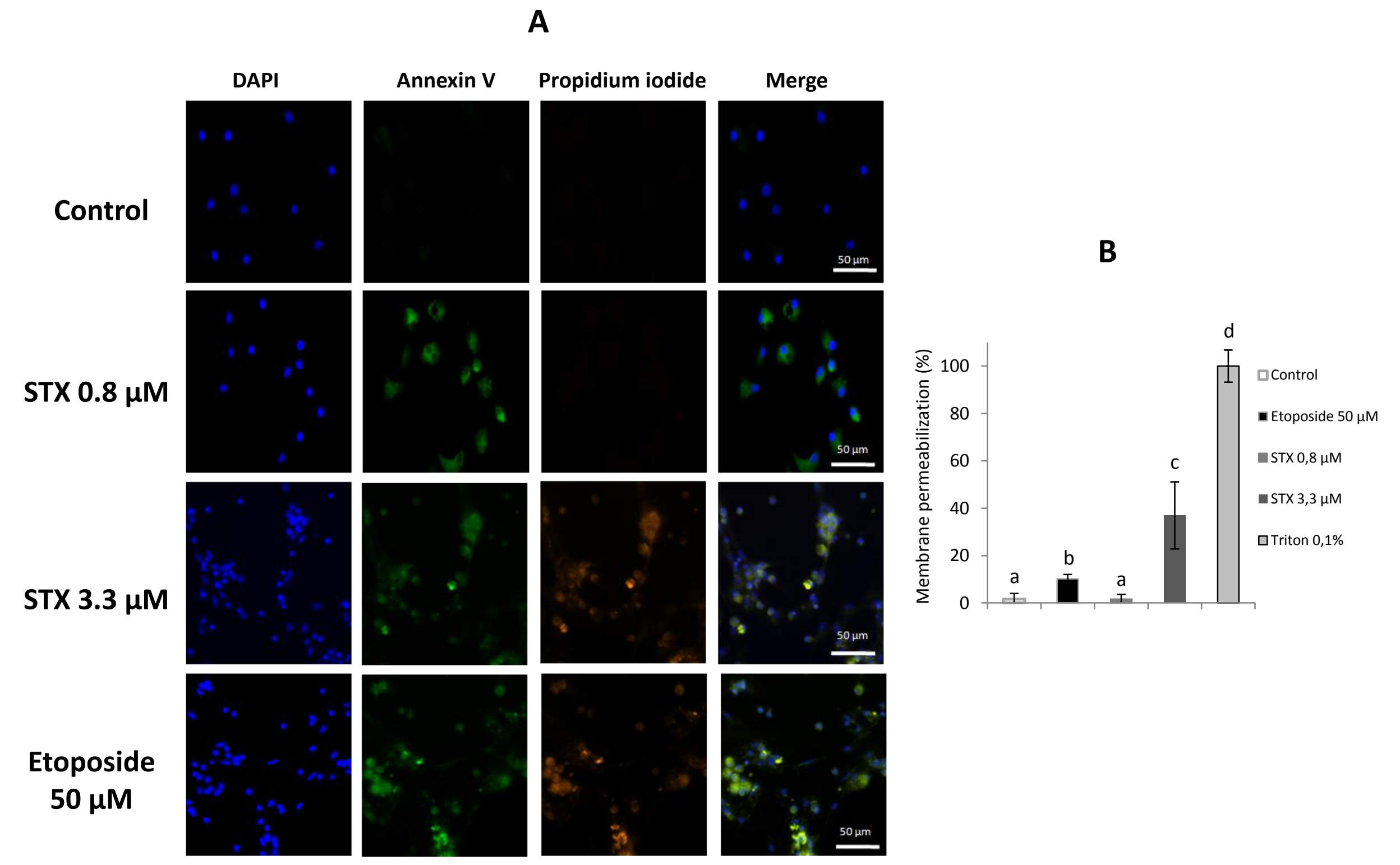


Figure 3

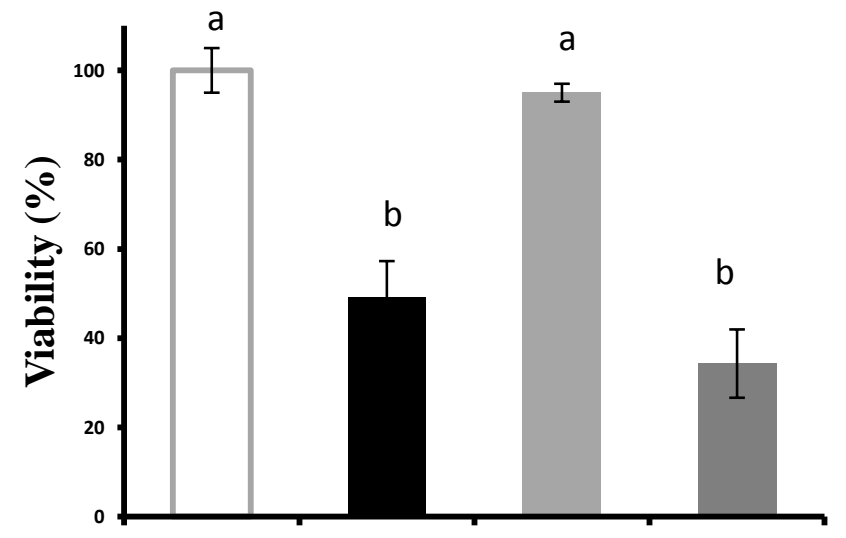

$\square$ Control

- Etoposide $50 \mu \mathrm{M}$

- STX $0,8 \mu \mathrm{M}$

$=\operatorname{STX} 3.3 \mu \mathrm{M}$ 
Etoposide

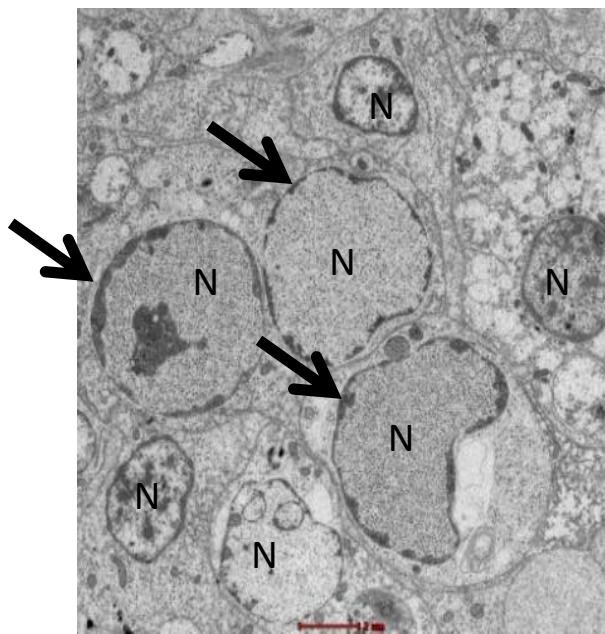

STX $0.8 \mu \mathrm{M}$

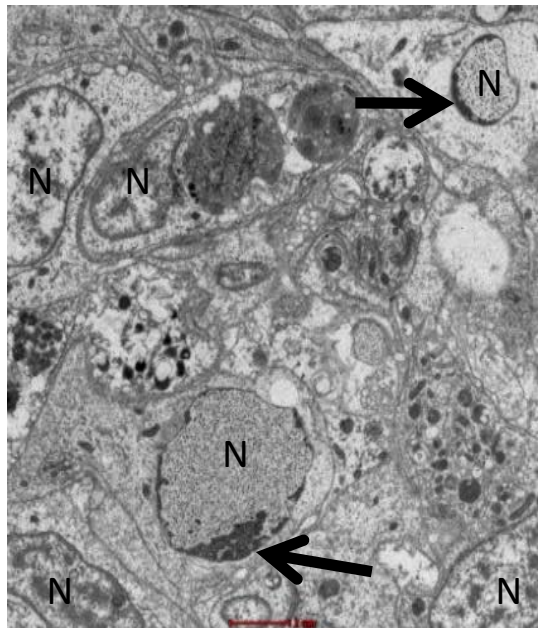

Control

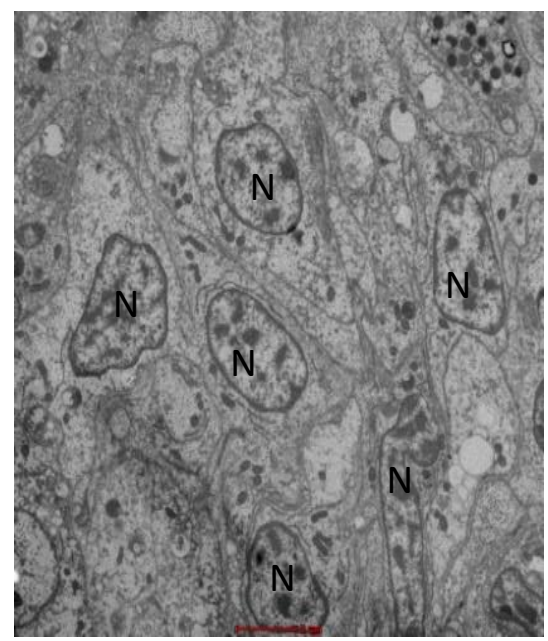


A

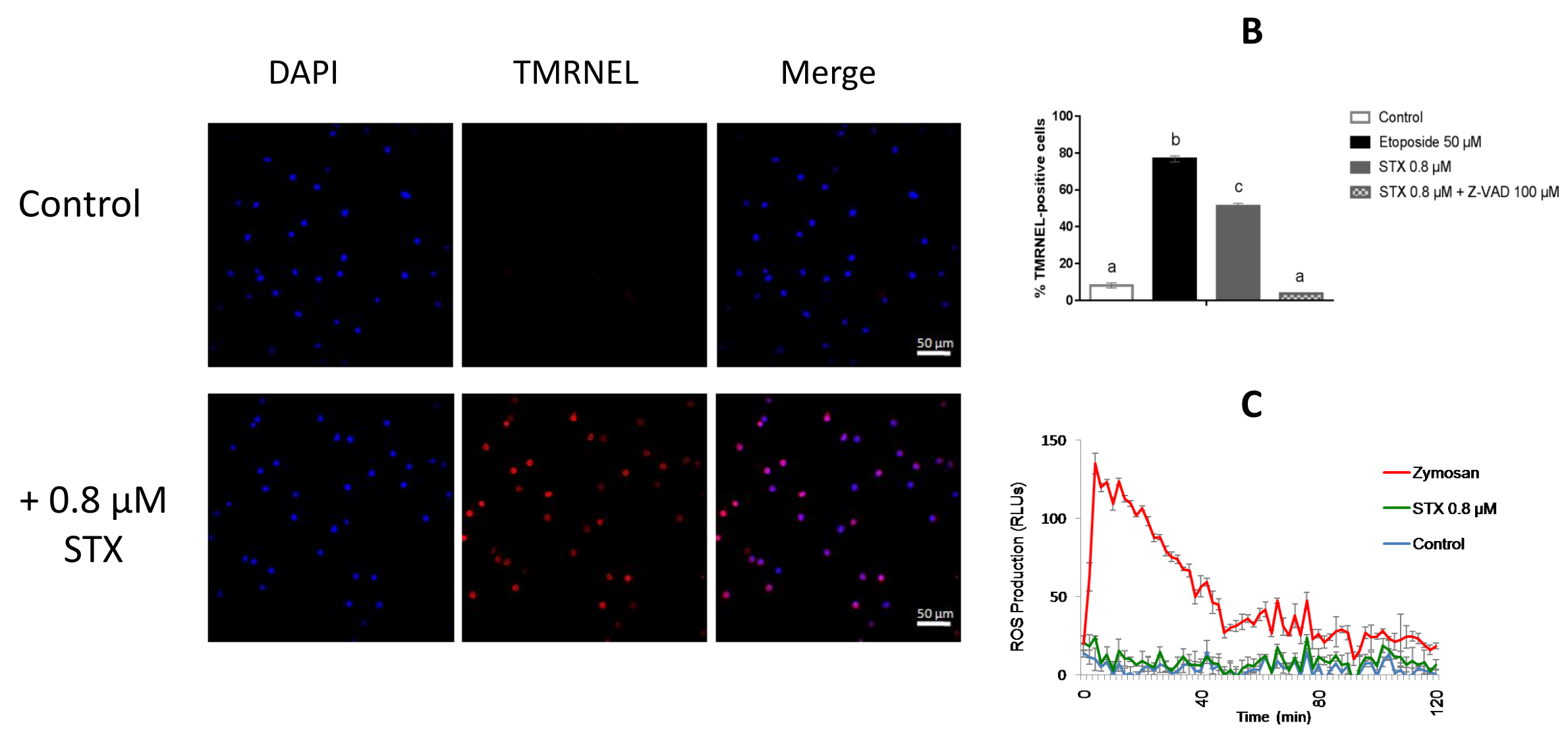


Figure 6

A

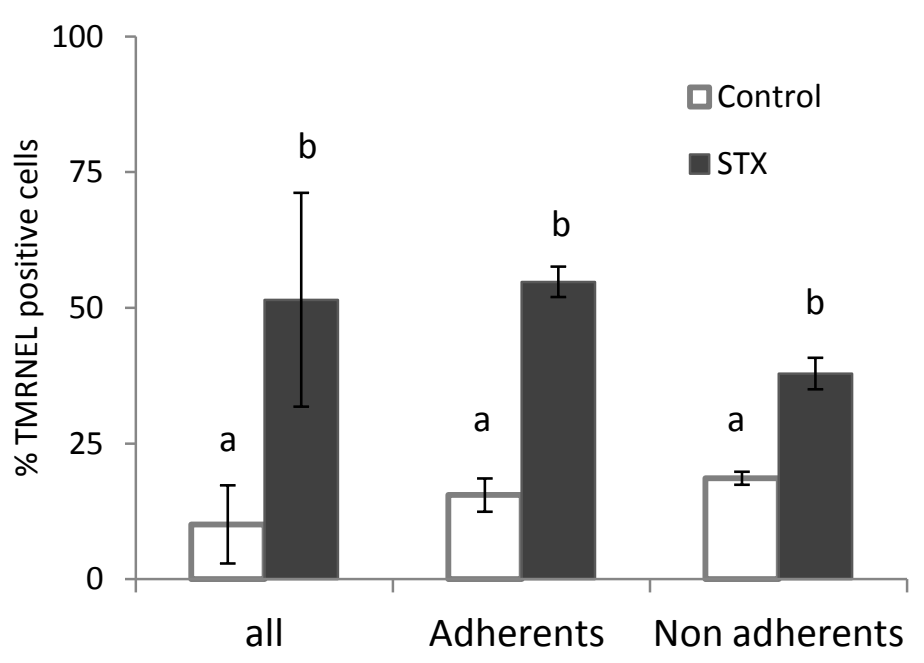

B

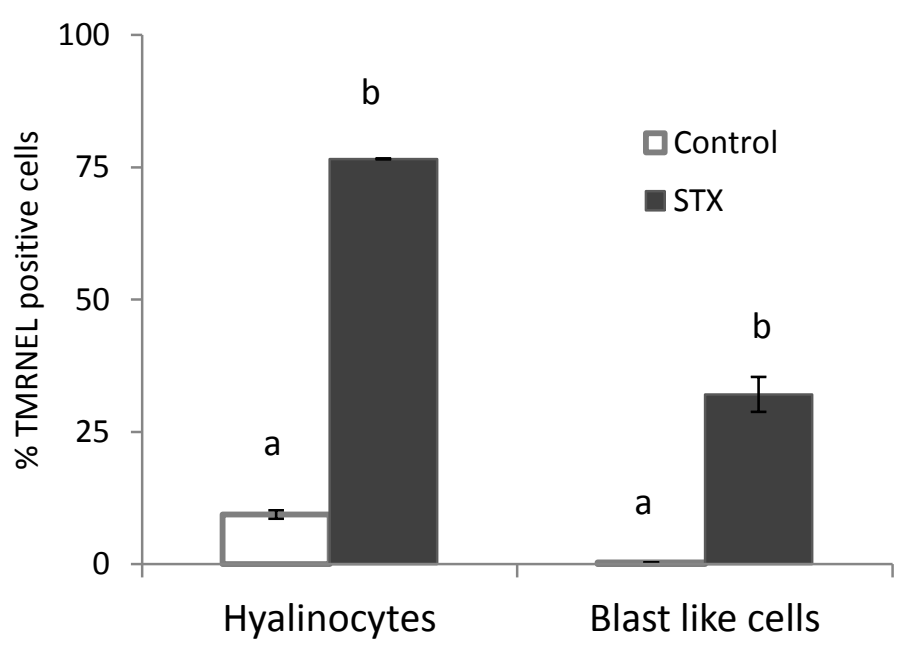


Figure 7

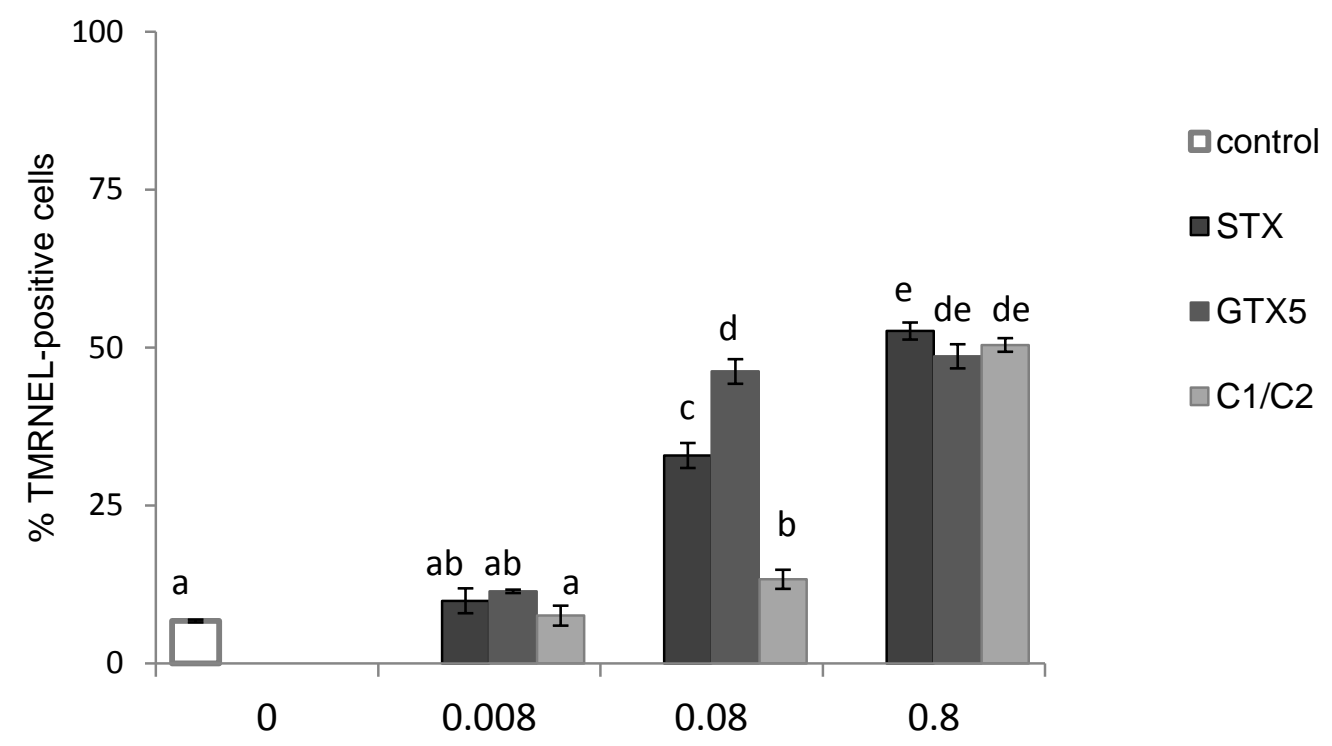

Toxins $(\mu \mathrm{M})$ 


\section{Supplementary figures}

Figure S1. Spectral analysis of $C$. gigas hemocytes exposed to Gua-Cou and STX-Cou. Linear unmix with the 2 reference spectra of Mitotracker Red (red) and coumarin (green) was applied to hemocytes exposed to Gua-Cou or STX-Cou for $3.5 \mathrm{~h}$. Scale bar: $10 \mu \mathrm{m}$.

Figure S2. Time dependence of nuclear DNA fragmentation in $C$. gigas hemocytes exposed to STX. Percentage of TMRNEL-positive cells in hemocytes not exposed (white column) and exposed (dark grey column) to $0.8 \mu \mathrm{M} \mathrm{STX}$ for $3.5 \mathrm{~h}$ and $24 \mathrm{~h}$. Bars represent the mean \pm standard errors from three independent experiments. Different superscripts (a and b) indicate statistically-significant differences ( $p<0.001$; two way anova/ Tukey HSD).

Figure S3. Flow cytometry analysis of STX toxicity in hyalinocyte and blast-like cells. TMRNEL-positive cells of unexposed hemocytes (top row) or hemocytes exposed for $3.5 \mathrm{~h}$ to $0.8 \mu \mathrm{M}$ STX (bottom row). 10,000 cells of each condition and TMRNEL-positive hemocytes cell populations were sorted by size. 